\title{
The Effect of Blood and Seminal Plasma Heavy Metal and Trace Element Levels on Sperm Quality
}

\author{
Kan ve Seminal Plazma Ağır Metal ve \\ Eser Element Düzeylerinin \\ Sperm Kalitesine Etkisi
}

\author{
Salih KAHRAMAN, a \\ Hikmet HASSA, ${ }^{b}$ \\ Ahmet KARATAȘ, ${ }^{\circ}$ \\ Halil ILGIN ${ }^{d}$
}

aDepartment of Obstetrics and Gynecology, Tokat State Hospital, Tokat

bDepartment of Obstetrics and Gynecology, Eskișehir Osmangazi University

Faculty of Medicine, Eskişehir 'Department of Obstetrics and Gynecology, Düzce University Faculty of Medicine, Düzce

Department of Obstetrics and Gynecology, Bahçe State Hospital, Osmaniye

Geliş Tarihi/Received: 19.09 .2011 Kabul Tarihi/Accepted: 19.06 .2012

\section{Yazıșma Adresi/Correspondence:} Ahmet KARATAŞ

Düzce University Faculty of Medicine, Department of Obstetrics and Gynecology, Düzce,

TÜRKIYE/TURKEY

akaratas1973@hotmail.com

\begin{abstract}
Objective: Infertility is shown in approximately $10-15 \%$ of the couples. Male infertility is responsible for at least $50 \%$ of them. In these infertile couples, male is responsible alone in $30 \%$ while male and female are responsible together in $20 \%$. The semen analysis is the first laboratory test which should be done to evaluate the male infertility. Heavy metals and trace elements affect sperm production, motility and morphology. The aim of this study is to determine zinc, copper, lead and cadmium levels in blood and seminal samples of men and to evaluate their relationship with sperm quality parameters. Material and Methods: Forty-two men with abnormal sperm quality parameters and 10 control subjects were included in the study. Zinc, copper, cadmium and lead levels were measured in blood and semen. The results were compared. Results: Lead levels in blood, cadmium levels both in blood and seminal plasma were significantly higher in men with abnormal sperm analyses $(\mathrm{p}<0.05)$. There was a positive correlation between seminal plasma zinc level and sperm count, motility and morphology $(\mathrm{p}<0.001)$ and between seminal plasma copper level and sperm count and morphology $(\mathrm{p}<0.05)$. There was a negative correlation between lead level and sperm count, motility and morphology $(\mathrm{p}<0.001)$. Likewise, there was a negative correlation between blood cadmium level and sperm motility and morphology $(\mathrm{p}<0.05)$ and between seminal plasma cadmium level and sperm motility $(\mathrm{p}<0.05)$. Conclusion: Zinc and copper affect sperm quality positively whereas lead and cadmium shows a negative effect. Exposure to heavy metals is an important etiology in the male infertility problem and should be treated seriously.
\end{abstract}

Key Words: Smoking; metals, heavy; trace elements; infertility, male

ÖZET Amaç: İnfertilite, çiftlerin \%10-15'inde görülmektedir. En az \%50'sinde erkek infertilitesi sorumludur. Bu infertil çiftlerin \%30'unda tek başına erkek, \%20'sinde de kadın faktörü ile beraber sorumludur. Erkek infertilitesini değerlendirmek için ilk yapılması gereken test semen analizidir. Ağır metaller ve eser elementler sperm üretimini, motilitesini ve morfolojisini etkilemektedir. $\mathrm{Bu}$ çalışma erkeklerin kan ve seminal örneklerinde çinko, bakır, kurşun ve kadmiyum düzeylerini saptamak ve sperm parametreleri ile ilişkilerini araştırmak için yapıldı. Gereç ve Yöntemler: Çalışmaya anormal sperm parametreli kırk iki ve kontrol grubu olarak 10 kişi dahil edildi. Kanda ve semende çinko, bakır, kadmiyum ve kurşun düzeyleri ölçüldü. Anormal sperm parametreli erkeklerin sonuçları normal sperm parametreleri ile karşılaştırıldı. Bulgular: Sperm analizi anormal olan erkeklerde kurşun seviyesi kanda, kadmiyum seviyesi hem kanda hem de seminal plazmada anlamlı olarak yüksekti $(\mathrm{p}<0,05)$. Seminal plazma çinko seviyesi ile sperm sayısı, motilitesi ve morfolojisi arasında $(\mathrm{p}<0,001)$ ve seminal plazma bakır seviyesi ile sperm sayısı ve morfolojisi arasında pozitif korelasyon saptandı $(\mathrm{p}<0,05)$. Kurşun seviyesi ile sperm sayı, motilite ve morfoloji arasında negatif korelasyon vardı ( $<<0,001)$. Benzer şekilde kan kadmiyum düzeyi ile sperm motilite ve morfolojisi arasında $(p<0,05)$ ve seminal plazma kadmiyum düzeyi ile sperm motilitesi arasında $(\mathrm{p}<0,05)$ negatif korelasyon vardı. Sonuç: Çinko ve bakır sperm kalitesini pozitif etkilerken kurşun ve kadmiyum negatif korelasyon göstermektedir. Erkek infertilitesi varlığında ağır metallere maruz kalmak önemli bir etkendir ve ciddi olarak tedavi edilmelidir.

Anahtar Kelimeler: Sigara içme; metaller, ağır; eser elementler; kısırlık, erkek 
$\mathrm{T}$ he infertility is shown in approximately 10 $15 \%$ of the couples. ${ }^{1}$ Male infertility is responsible for at least $50 \%$ of them. In these infertile couples, male is responsible alone in 30\% while male and female are responsible together in $20 \% .^{2}$ The semen analysis is the first laboratory test which should be done to evaluate the male infertility. The routine semen analysis was standardized by World Health Organization (WHO) which consists of microscopic parameters such as sperm concentration, motility and morphological detection, besides macroscopical evaluation of the ejaculate. ${ }^{3}$ Exposure to the environmental agents such as cigarette, warmth, electromagnetic energy and radiation have been shown to be effect fertility negatively via affecting the gonadal development, maturation of germ cells, fertilization and endocrine system. ${ }^{4,5}$ Not only the type of material, but also the exposure time determines the effect of these factors on reproductive health. Heavy metals cause abnormal sperm production based on their type, exposure duration and severity. ${ }^{6}$ While some trace elements have toxic effects, others may have positive and usable effects on reproductive system. ${ }^{7,8}$ The aim of this study was to determine zinc (Zn), copper $(\mathrm{Cu})$ and heavy metals such as lead $(\mathrm{Pb})$ and cadmium (Cd) levels in blood and seminal samples of men, and to evaluate their relationship with sperm quality parameters.

\section{MATERIAL AND METHODS}

This prospective study was performed in Eskisehir Osmangazi University School of Medicine, Department of Obstetrics and Gynecology, Center for Reproductive Health. Fifty-two cases (with abnormal semen analysis results $n=42$; normozoospermic cases, $n=10$ ) were included after obtaining the permission of the Faculty Ethics Board. The seminal plasma (SP) and blood samples were taken from randomly selected volunteer males, after they have signed a consent form. Both groups (with abnormal semen analysis and with normal semen analysis) comprised the infertile population.

The history was reviewed (diseases, trauma, exposure to teratogen and toxic agents and habits) in all cases. The spermiograms were taken from ca- ses via masturbation technique in sterile polyethylene cups after 3-5 days of abstinence. While the volume, $\mathrm{pH}$, viscosity, sperm numbers and motility were evaluated according to WHO criteria, the morphology was evaluated according to Kruger criteria in ejaculate after liquefaction. HamiltonThorne-Multispecies HTM-IVOS was used for sperm count and defined as million/mL. Morphological investigation was carried out using Papanicolaou stain.

After sperm analysis, the semen samples were centrifuged (1400 rpm for $10 \mathrm{~min}$ ) in room temperature, the SP were obtained ${ }^{8}$ and kept at $-20^{\circ} \mathrm{C}$ until the analysis of $\mathrm{Zn}, \mathrm{Cu}, \mathrm{Cd}$ and $\mathrm{Pb}$ levels. Zinc, $\mathrm{Cu}, \mathrm{Cd}$ and $\mathrm{Pb}$ levels were measured in whole blood (WB), blood plasma (BP) and SP, in all cases. Samples of WB were taken into ethylenediaminetetraacetic acid(EDTA) containing tubes and BP was put into heparin-containing tubes. Supernatants were obtained followed by centrifugation $(2000 \mathrm{xg}, 5 \mathrm{~min})^{9}$ and kept at $-20^{\circ} \mathrm{C}$ until analysis.

Heavy-metal analytical solutions were prepared by dilution in distilled water in BP and SP. Organics were removed by burning and applying acid. The burning procedure was applied initially to the WB samples at $600^{\circ} \mathrm{C}$ to constant weight. After the burning procedure, $0.5 \mathrm{~mL}$ of concentrated $\mathrm{HNO}_{3}$ and $0.5 \mathrm{~mL}$ of an acid mixture $(2 \%$ $\mathrm{v} / \mathrm{v} \mathrm{HClO}_{4} / \mathrm{HNO}_{3}$ ) were added. After this procedure, the samples were incubated in a water bath at $60^{\circ} \mathrm{C}$, and the analytical solutions were prepared. The final elemental analysis was performed with a polarized Zeeman atomic absorption spectrophotometer (Hitachi 180-70; Mountain View, CA, USA).

The SPSS software (SPSS 13, Chicago, IL, USA) was used for statistical analyses. Descriptive parameters are presented as means \pm standard deviation, median $\left(25^{\text {th }}-75^{\text {th }}\right.$ percentiles $)$ or as percentages. Fisher Exact test were used for $2 \times 2$ categorical variables. MannWhitney-U test and Student's t test were used for comparing medians and means in two groups respectively. Spearman's correlations were used to analyze the differences in means and proportions between the groups. Kruskal-Wallis 
analysis was performed for analyzing continuous variables in three or more groups, and Bonferroni adjusted Mann Whitney-U test was performed for multiple comparisons $\left(\alpha^{*}=0.05 / 21=0.0024\right)$. A p-value of $<0.05$ was considered significant.

\section{RESULTS}

Age, infertility time, cigarette habit, semen analysis and element levels in blood and SP were compared in controls $(n=10)$ and infertile patients $(n=42)$ groups. Statistical differences were not detected between the groups for age, infertility time or cigarette smoking ( $\mathrm{p}=0.534 ; \mathrm{p}=0.910 ; \mathrm{p}=0.366$, respectively). Five of 10 males (50\%) with normal semen analysis and 26 of 42 males (61.9\%) with abnormal semen analysis were smoking cigarettes. Average amount of smoking was 20 to 40 cigarettes/day with a mean duration of $13.00 \pm 5.24$ years. While there were no difference for $\mathrm{pH}$, semen volume and $\mathrm{Pb}$ level in SP between the groups, there was a significant difference for the other variables tested (Table 1).
Patients with abnormal sperm parameters $(\mathrm{n}=42)$ were divided into subgroups according to sperm number, motility and morphology. They were compared with subjects who had normal sperm quality parameters. Semen analysis, blood and SP element levels of each group are shown in Table 2. While the mean age and mean infertility time, smoker (package/year), semen $\mathrm{pH}$, and volume, BP Zn, SP Zn, SP Cu, SP Pb, SP Cd were simi$\operatorname{lar}(\mathrm{p}=0.906, \mathrm{p}=0.396, \mathrm{p}=0.132, \mathrm{p}=0.267, \mathrm{p}=0.234$, $\mathrm{p}=0.012, \mathrm{p}=0.212, \mathrm{p}=0.014, \mathrm{p}=0.121, \mathrm{p}=0.023$, respectively), there were statistical significance in total motility, rapid progressive motility , morphology, BP Cu, WB Pb, WB Cd between the groups $(\mathrm{p}<0.001, \mathrm{p}<0.001, \mathrm{p}<0.001, \mathrm{p}<0.001$, $\mathrm{p}=0.002, \mathrm{p}<0.001$, respectively) (Table 2 ).

Education status (primary, high school and university), jobs (official, farmer, dye and metal industry), family history of infertility, presence of undescended testicles or varicocele, premature ejaculation and low libido were similar among subgroups. The $\mathrm{p}$ values were $0.657,0.760,0.215$,

TABLE 1: Distribution of age, infertility time, cigarette use, semen parameters, trace elements and heavy metal levels in blood and seminal plasma of males having normal and abnormal sperm parameters.

\begin{tabular}{|c|c|c|c|}
\hline & $\begin{array}{l}\text { Normal sperm parameters }(n=10) \\
\qquad M(25-75 \text { percentiles) }\end{array}$ & $\begin{array}{l}\text { Abnormal sperm parameters }(n=42) \\
\text { M ( } 25-75 \text { percentiles })\end{array}$ & $\mathrm{p}$-value \\
\hline Male age (year) & $32.80 \pm 5.88$ & $31.69 \pm 4.95$ & 0.534 \\
\hline Infertility duration (year) & $5.35 \pm 3.12$ & $5.44 \pm 3.61$ & 0.910 \\
\hline Smoker (n) & $5 / 10$ & $26 / 42$ & 0.366 \\
\hline Smoker (package/year) & $4(0-12.8)$ & $8(0-15)$ & 0.622 \\
\hline $\mathrm{pH}$ & $8(8-8)$ & $8(8-8)$ & 0.718 \\
\hline Volume $(\mathrm{mL})$ & $3.75(2.5-5)$ & $3.4(2.5-5)$ & 0.954 \\
\hline Number (million/mL) & $61.5(38-132)$ & $19(0.5-48)$ & 0.002 \\
\hline T. Motility (\%) & $65(60-76)$ & $31(0-46)$ & $<0.001$ \\
\hline RP. Motility (\%) & $48(38-56)$ & $16(0-29)$ & $<0.001$ \\
\hline Morphology (\%) & $24.5(19-30)$ & $5.5(0-11)$ & $<0.001$ \\
\hline $\mathrm{BP} Z n(\mu g / L)$ & $1645(1420-2170)$ & $1100(950-1340)$ & $<0.001$ \\
\hline SP Zn (mg/L) & $140.8(115.6-152.5)$ & $103.7(103.7-124.8)$ & 0.023 \\
\hline BP Cu $(\mu g / L)$ & $1320(1320-1705)$ & 1015 (1015-1162) & $<0.001$ \\
\hline $\mathrm{SPCu}(\mu g / L)$ & 765 (510-928) & $560(560-692)$ & 0.039 \\
\hline WB Pb $(\mu g / L)$ & $26.85(24.2-29.1)$ & $32.45(28.2-40.8)$ & 0.001 \\
\hline $\mathrm{SP} \mathrm{Pb}(\mu g / L)$ & $10.3(9.9-10.9)$ & $11.5(10.2-13.4)$ & 0.065 \\
\hline WB Cd $(\mu \mathrm{g} / \mathrm{L})$ & $0.95(0.9-1.1)$ & $1.3(1.2-1.5)$ & $<0.001$ \\
\hline $\mathrm{SPCd}(\mu \mathrm{g} / \mathrm{L})$ & $0.65(0.6-1)$ & $1.2(0.8-1.3)$ & 0.006 \\
\hline
\end{tabular}

T. Motility: Total motility; RP. Motility: Rapid progressive motility; BPZn: Blood plasma zinc; SPZn: Seminal plasma zinc; BPCu: Blood plasma copper; SPCu: Seminal plasma copper; WBPb: Whole blood lead; SPPb: Seminal plasma lead; WBCd: Whole blood cadmium; SPCd: Seminal plasma cadmium; M: Median. 


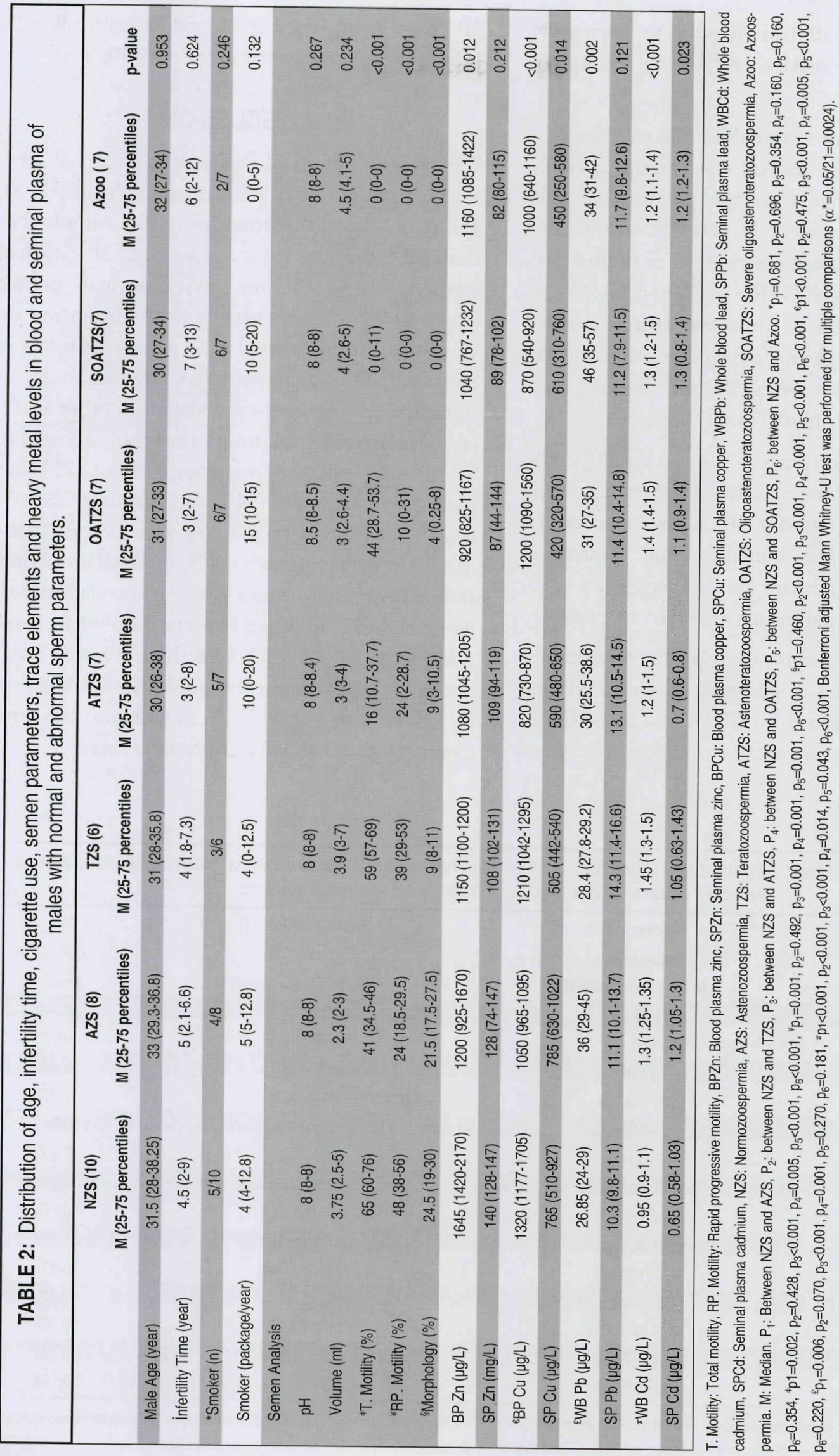


0.512 , for family infertility history, for varicocele, for premature ejaculation and for low libido, respectively.

The participants with abnormal semen analyses were further divided into two groups as smokers and non smokers. Semen parameters, trace element and heavy metal levels in blood and SP of these two groups were analyzed. None of them were found significant (Table 3). When all participants with normal or abnormal semen analysis included; very slight negative correlation was detected in only between SP $\mathrm{Zn}$ and smoking cigarette as packs/year ( $\mathrm{p}=0.033, \mathrm{r}=-0.295)$.

The correlation analysis showed that BP Zn level was associated with increased total motility and rapid progressive motility. SP Cu level was associated with decrease in semen volume, increase in sperm number and better morphology. The significant correlation coefficients are given in Table 4.

There was a positive correlation between blood and SP Zn and Cd, whereas an inverse relation existed between blood $\mathrm{Zn}, \mathrm{SP} \mathrm{Cu}$ and blood Cd level. There was also a negative correlation between
SP Zn, WB and SP Cd and blood Pb levels. WB Cu level was negatively correlated with $\mathrm{Pb}$ level.

\section{DISCUSSION}

The tolerable limits of exposure to chemical substances have not been defined in our country. Zn values in SP were approximately 100 times higher than BP. Subjects with lower levels of SP Zinc had significantly lower numbers of normal sperms. There are conflicting results in the literature on this issue. While $\mathrm{Zn}$ level in SP was found lower in males with abnormal sperm in a previous study, no significant difference was detected in other studies. ${ }^{7,10,11}$ Carreras et al. found that the $\mathrm{Zn}$ levels in SP of males with asthenozoospermia (AZS) was higher than males with oligozoospermia (OZS), oligoasthenozoospermia (OAZS), azoospermia (Azoo) and normozoospermia (NZS) $(\mathrm{p}<0.001)$, and they showed that there was a positive correlation between $\mathrm{Zn}$ level in SP and sperm number in these subjects $(\mathrm{p}<0.01) .{ }^{11}$ Although there was not a statistical significance, in this study the $\mathrm{Zn}$ levels in $\mathrm{BP}$ and SP were higher in males with normal sperm compared to males with abnormal sperm.

TABLE 3: Comparison of sperm parameters, trace element and heavy metal levels in seminal plasma and blood among smoker and non smoker males with abnormal sperm parameters.

\begin{tabular}{|c|c|c|c|}
\hline & $\begin{array}{c}\text { Smoker }(n=26) \\
\text { (mean } \pm S D) \\
M(25-75 \text { percentiles })\end{array}$ & $\begin{array}{l}\text { Non Smoker }(n=16) \\
\quad(\text { mean } \pm S D) \\
M(25-75 \text { percentiles })\end{array}$ & $p$-value \\
\hline $\mathrm{pH}$ & $8(8-8.5)$ & $8(8-8)$ & 0.343 \\
\hline Volume (mL) & $3(2.4-4.1)$ & $4.3(2.6-6.5)$ & 0.178 \\
\hline Number (million/mL) & $17(0.9-44.3)$ & $21(0-65)$ & 0.765 \\
\hline T. Motility (\%) & $27(0-45.5)$ & $34(0-49.8)$ & 0.927 \\
\hline RP. Motility (\%) & $12.5(0-30)$ & $23(0-29.8)$ & 0.861 \\
\hline Morphology (\%) & $7(0-11.8)$ & $1.5(0-16)$ & 0.800 \\
\hline $\mathrm{BP} Z n(\mu \mathrm{g} / \mathrm{L})$ & $1080(887-1212)$ & $1130(990-1400)$ & 0.191 \\
\hline SP Zn (mg/L) & 94 (76-122) & $113(83-139)$ & 0.187 \\
\hline BP Cu $(\mu g / L)$ & $1015(835-1177)$ & $1015(913-1133)$ & 0.938 \\
\hline $\mathrm{SP} C u(\mu g / L)$ & $560(450-682)$ & $550(288-708)$ & 0.437 \\
\hline WB Pb ( $\mu g / L)$ & $31(28-42)$ & $36(30-40)$ & 0.437 \\
\hline $\mathrm{SPPb}(\mu \mathrm{g} / \mathrm{L})$ & $11.5(9.6-12.8)$ & $12.6(10.8-15.3)$ & 0.057 \\
\hline WB Cd ( $\mu g / L)$ & $1.4(1.2-1.5)$ & $1.3(1.2-1.5)$ & 0.425 \\
\hline SP Cd $(\mu g / L)$ & $1.2(0.8-1.3)$ & $1.2(0.7-1.3)$ & 0.774 \\
\hline
\end{tabular}

T. Motility: Total motility; RP. Motility: Rapid progressive motility; BPZn: Blood plasma zinc; SPZn: Seminal plasma zinc; BPCu: Blood plasma copper; SPCu: Seminal plasma copper; WBPb: Whole blood lead; SPPb: Seminal plasma lead; WBCd: Whole blood cadmium; SPCd: Seminal plasma cadmium; SD: Standard deviation; M: Median. 
TABLE 4: Relationships of the levels of trace elements, heavy metals and sperm parameters in SP and blood.

\begin{tabular}{|c|c|c|c|c|c|c|}
\hline & $\mathrm{pH}$ & Volume & Number & T. Motility & RP. Motility & Morphology \\
\hline $\mathrm{BP} Z \mathrm{n}$ & -0.28 & - & - & 0.29 & 0.31 & 0.38 \\
\hline$p$ & 0.044 & & & 0.033 & 0,023 & 0.005 \\
\hline $\mathrm{SP} Z \mathrm{n}$ & - & - & 0.43 & - & 0.49 & 0.48 \\
\hline$p$ & & & 0.001 & & $<0.001$ & $<0.001$ \\
\hline $\mathrm{BPCu}$ & - & - & 0.36 & 0.62 & 0.37 & 0.38 \\
\hline$p$ & & & 0.007 & $<0.001$ & 0.006 & 0.005 \\
\hline SP Cu & - & -0.30 & 0.38 & - & - & 0.46 \\
\hline$p$ & & 0.026 & 0.005 & & & 0.001 \\
\hline WB Pb & - & - & -0.49 & -0.56 & -0.57 & $-0,43$ \\
\hline$p$ & & & $<0.001$ & $<0.001$ & $<0.001$ & 0.001 \\
\hline $\begin{array}{r}\mathrm{SP} P b \\
p\end{array}$ & - & - & - & - & - & - \\
\hline WB Cd & - & - & - & - & -0.28 & -0.37 \\
\hline$p$ & & & & & 0.040 & 0.006 \\
\hline $\begin{array}{r}\mathrm{SP} C d \\
p\end{array}$ & - & - & - & . & $\begin{array}{l}-0.38 \\
0.005\end{array}$ & - \\
\hline
\end{tabular}

BPZn: Blood plasma zinc; SPZn: Seminal plasma zinc; BPCu: Blood plasma copper; SPCu: Seminal plasma copper; WBPb: Whole blood lead; SPPb: Seminal plasma lead; WBCd: Whole blood cadmium; SPCd: Seminal plasma cadmium; T. Motility: Total motility; RP. Motility: Rapid progressive motility.

We found a positive correlation between $\mathrm{Zn}$ level in BP and total motility, rapid progressive motility and morphology, and a negative correlation was found with seminal $\mathrm{pH}$ ( $\mathrm{p}=0.044)$. Some of the studies showed a positive correlation of $\mathrm{Zn}$ concentration in SP with sperm number and motility, while in others no correlation was found. ${ }^{7,10-15} \mathrm{Ho}^{-}$ wever, several investigators concluded that higher Zn level in SP effected spermatozoa motility and morphology negatively. ${ }^{16,17}$

There is not a consensus about the effects of $\mathrm{Cu}$ on in-vivo fertility. In this study we detected that $\mathrm{Cu}$ levels in BP was significantly higher in males with normal sperm morphology and function compared to AZS, asthenoteratozoospermia (ATZS) and severe oligoasthenoteratozoospemia (SOATZS) $(\mathrm{p}<0.001)$. Stankovic and Mikac-Devic have shown that higher $\mathrm{Cu}$ levels in males were associated with OZS. ${ }^{18}$ On the other hand, Skandhan and Mazumdar reported that the sperm concentration decreased with decreasing $\mathrm{Cu}$ concentration, and sperm motility decreased with higher $\mathrm{Cu}$ concentration. ${ }^{19}$ Stanwell-Smith et al. did not find any difference in SP Cu levels of males with normal and abnormal sperm parameters. ${ }^{20}$ Jockenhovel et al. reported a weak but significant correlation between seminal $\mathrm{Cu}$ concentration and sperm concentration, motility and morphology. ${ }^{21}$ Wong et al. found BP Cu levels similar in patients with abnor$\mathrm{mal}$ and normal sperms, but a positive correlation was found between $\mathrm{BP} \mathrm{Cu}$ concentration and sperm motility. ${ }^{9}$ Huang et al. detected higher levels of SP Cu in patients with AZS compared to NZS group. ${ }^{15}$ They also reported a positive correlation between SP Cu levels and sperm count. The present study showed lower $\mathrm{Cu}$ levels in SP of males with teratozoospermia (TZS), ATZS, oligoasthenoteratozoospermia (OATZS), SOATZS, and Azoo compared to NZS and AZS, although not statistically significant. Concordant with the literature data, we detected a positive correlation between BP $\mathrm{Cu}$ and sperm number, total motility, rapid progressive motility and morphology. Additionally a positive correlation was found between SP Cu level and sperm count and morphology, and a negative correlation was detected with the semen volume.

It has been suggested that the adverse effects of $\mathrm{Pb}$ on male fertility occurs at higher values than $40 \mu \mathrm{g} / \mathrm{dL} .{ }^{22}$ However, with even lower blood $\mathrm{Pb}$ le- 
vels such as $20-50 \mu \mathrm{g} / \mathrm{dL}$, adverse changes on fertility may be determined in animal studies. ${ }^{23}$ In this study, mean $\mathrm{Pb}$ levels in WB were detected higher in males with ATZS and OATZS compared to NZS ( $\mathrm{p}<0.001, \mathrm{p}=0.001$, respectively). Chia et al. found that $\mathrm{Pb}$ level in $\mathrm{WB}$ was higher in patients with abnormal sperm motility $(72 \mu \mathrm{g} / \mathrm{L}$ versus $51 \mu \mathrm{g} / \mathrm{L}$ respectively, $\mathrm{p}=0.0034) .{ }^{6}$ Saaranen et al. found that the $\mathrm{Pb}$ levels in SP was significantly lower $(1.7 \mu \mathrm{g} / \mathrm{L}$ vs $3.6 \mu \mathrm{g} / \mathrm{L}$ ) in males with abnormal sperms. ${ }^{24} \mathrm{~Pb}$ levels were inversely associated with semen volume, sperm number, density, and abnormal sperm motility, and morphology. ${ }^{6,22,25-27}$ Our study also showed a negative correlation between $\mathrm{Pb}$ level in WB with sperm number, total motility, rapid progressive motility and morphology. Although Liou et al. found that fertility was relatively lower in men whose $\mathrm{Pb}$ level in $\mathrm{WB}>30 \mu \mathrm{g} / \mathrm{dL}$ but there was not a certain dose-response relationship, Joffe et al. showed that any detectable effect was not found on male fertility in European industry region. ${ }^{28,29}$ The half-life of $\mathrm{Pb}$ in blood is $28-30$ days. ${ }^{30}$ Several authors have investigated the effect of exposure duration to $\mathrm{Pb}$ on male fertility. ${ }^{31,32}$ Lancranjan et al. showed that in patients who worked 8.5 years in a battery factory had a mean blood $\mathrm{Pb}$ of 41-75 $\mu \mathrm{g} / \mathrm{dL}$ and had higher incidence of OZS, AZS, and TZS. ${ }^{31}$ However, Coste et al. did not find any effect of $\mathrm{Pb}$ exposure on male reproduction. ${ }^{33}$

Higher levels of Cd in WB compared to SP was associated with a significant decrease in sperm count, especially at a level higher than $1.5 \mu \mathrm{g} / \mathrm{L}{ }^{34} \mathrm{In}$ addition, a relation has been shown between lower levels of Cd in SP and low semen volume and sperm motility. ${ }^{13}$ High levels of SP Cd was found to be associated with abnormal sperm parameters. ${ }^{7,21,24}$ We found higher levels of Cd both in WB and $\mathrm{SP}$ in males with abnormal sperms compared to NZS, but the significance was observed between NZS and AZS, TZS, ATZS, Azoo in WB. We observed a negative correlation between $\mathrm{Cd}$ levels in WB and rapid progressive motility and morphology, in SP and rapid progressive motility. Chia et al. reported a negative correlation between $\mathrm{Cd} \mathrm{le-}$ vel in WB and seminal volume $(\mathrm{p}<0.05)$ and a pos- itive relation with abnormal sperm parameters and TZS. ${ }^{6} \mathrm{Xu}$ et al. reported a negative correlation between $\mathrm{Cd}$ concentration and semen volume, a negative effect on the prostate gland secreting. ${ }^{13}$ However, we could not find any correlation between semen quality and concentration with Cd level in SP. Exposure to Cd has been shown to be unrelated with semen quality and infertility. ${ }^{32,35}$

It has been reported that smoking negatively affects fertility both in men and women. ${ }^{36} \mathrm{We}$ did not find any significant difference between smoking habit and semen parameters. Gaur et al. found AZS in light smokers ( $<20$ pieces/day), TZS and further deterioration in sperm quality in heavy smokers ( $>40$ pieces/day). ${ }^{37} \mathrm{~A}$ meta-analysis showed that smoking was associated with significant reduction in semen quality. ${ }^{38}$ Another study showed that ejaculate volume and sperm count significantly decreased in smokers without any change in motility and morphology. ${ }^{39}$ Chia and Ong showed a decrease in sperm density and increase in abnormal morphology in heavy smokers (>20 pieces/day). ${ }^{40}$ Lower levels of $\mathrm{Zn}$ in SP were reported in smokers compared to non-smokers. ${ }^{12,41}$ In this study, when we compared smokers and non-smokers in males with normal and abnormal sperm parameters, $\mathrm{Zn}$ levels were lower in the smoking group in SP samples ( $\mathrm{p}=0.04)$. We did not find any difference for $\mathrm{Zn}, \mathrm{Cu}, \mathrm{Pb}$ and $\mathrm{Cd}$ levels between smokers and non-smokers in blood and SP in males with abnormal sperms. Chia et al. has shown a similar result. ${ }^{12}$ They found lower levels of $\mathrm{Zn}$ in SP samples in males with abnormal sperms. Cigarette smoke is an important source of $\mathrm{Pb}$ and $\mathrm{Cd}$ in the air. StanwellSmith et al. have reported a positive relationship between blood Cd levels and cigarette consumption; however, they did not determine any correlation between blood $\mathrm{Cd}$ levels and semen parameters or fertility status. ${ }^{20}$ Although our study population showed no clusters of specific occupational groups, subjects could have been exposed to chemical pollutants through air, water or food.

\section{LIMITATIONS}

There are limited number of patients in each group, especially in the control group, thus the results are 
far from reflecting the general population. Because of the completely normal volunteers could not be found for the control group, control subjects were selected from patients with normal semen analysis who had a pre-diagnosis of infertility.

\section{CONCLUSIONS}

Trace elements such as $\mathrm{Zn}$ and $\mathrm{Cu}$ have positive effects on sperm quality but heavy metals such as $\mathrm{Pb}$ and $\mathrm{Cd}$ have negative effects. Previous literature data have shown that there is a great heterogeneity in the relation between these elements and inferti- lity parameters. Therefore, every society should have its own epidemiological data to establish necessary precautions. In conclusion, exposure to heavy metals is an important etiology in the male infertility problem and should be treated seriously.

\section{Acknowledgements}

This study was presented at the $15^{\text {th }}$ World Congress on In Vitro Fertilization, Geneva, Switzerland, April 19-22, 2009 as a poster presentation. The authors thank to Prof. Atilla Yildirim (lived in between 1951-2009) for his scientific advice and development of this study.

\section{REFERENCES}

1. Mosher WD, Pratt WF. Fecundity and infertility in the United States: incidence and trends. Fertil Steril 1991;56(2):192-3.

2. Howards SS. Treatment of male infertility. N Engl J Med 1995;332(5):312-7.

3. World Health Organization. WHO Laboratory Manual for the Examination of Human Semen and Sperm-Cervical Mucus Interaction. $4^{\text {th }}$ ed. Cambridge: Cambridge University Press; 1999. p.1-138.

4. Sharara FI, Seifer DB, Flaws JA. Environmental toxicants and female reproduction. Fertil Steril 1998;70(4):613-22.

5. Sinawat $\mathrm{S}$. The environmental impact on male fertility. J Med Assoc Thai 2000;83(8):880-5

6. Chia SE, Ong CN, Lee ST, Tsakok FH. Blood concentrations of lead, cadmium, mercury, zinc, and copper and human semen parameters. Arch Androl 1992;29(2):177-83.

7. Umeyama $\mathrm{T}$, Ishikawa $\mathrm{H}$, Takeshima H, Yoshii S, Koiso K. A comparative study of seminal trace elements in fertile and infertile men. Fertil Steril 1986;46(3):494-9.

8. Saaranen M, Kantola M, Saarikoski S, VanhaPerttula T. Human seminal plasma cadmium: comparison with fertility and smoking habits. Andrologia 1989;21(2):140-5.

9. Wong WY, Flik G, Groenen PM, Swinkels DW, Thomas CM, Copius-Peereboom JH, et al. The impact of calcium, magnesium, zinc, and copper in blood and seminal plasma on semen parameters in men. Reprod Toxicol 2001;15(2):131-6.

10. Fuse H, Kazama T, Ohta S, Fujiuchi Y. Relationship between zinc concentrations in seminal plasma and various sperm parameters. Int Urol Nephrol 1999;31(3):401-8.

11. Carreras A, Mendoza C. Zinc levels in seminal plasma of fertile and infertile men. Andrologia 1990;22(3):279-83.
12. Chia SE, Ong CN, Chua LH, Ho LM, Tay SK. Comparison of zinc concentrations in blood and seminal plasma and the various sperm parameters between fertile and infertile men. J Androl 2000;21(1):53-7.

13. Xu B, Chia SE, Tsakok M, Ong CN. Trace elements in blood and seminal plasma and their relationship to sperm quality. Reprod Toxicol 1993;7(6):613-8.

14. Lewis-Jones DI, Aird IA, Biljan MM, Kingsland CR. Effects of sperm activity on zinc and fructose concentrations in seminal plasma. Hum Reprod 1996;11(11):2465-7.

15. Huang $Y L$, Tseng WC, Cheng SY, Lin TH. Trace elements and lipid peroxidation in human seminal plasma. Biol Trace Elem Res 2000;76(3):207-15.

16. Kvist $U$. Importance of spermatozoal zinc as temporary inhibitor of sperm nuclear chromatin decondensation ability in man. Acta Physiol Scand 1980;109(1):79-84.

17. Stegmayr B, Ronquist $\mathrm{G}$. Stimulation of sperm progressive motility by organelles in human seminal plasma. Scand J Urol Nephrol 1982; 16(2):85-90.

18. Stanković H, Mikac-Dević D. Zinc and copper in human semen. Clin Chim Acta 1976;70(1): 123-6.

19. Skandhan KP, Mazumdar BN. Semen copper in normal and infertile subjects. Experientia 1979;35(7):877-8.

20. Stanwell-Smith R, Thompson SG, Haines AP, Ward RJ, Cashmore G, Stedronska J, et al. A comparative study of zinc, copper, cadmium, and lead levels in fertile and infertile men. Fertil Steril 1983;40(5):670-7.

21. Jockenhövel F, Bals-Pratsch M, Bertram HP, Nieschlag E. Seminal lead and copper in fertile and infertile men. Andrologia 1990;22(6): 503-11.
22. Alexander $\mathrm{BH}$, Checkoway $\mathrm{H}$, van Netten $\mathrm{C}$, Muller CH, Ewers TG, Kaufman JD, et al. Semen quality of men employed at a lead smelter. Occup Environ Med 1996;53(6):411-6.

23. Apostoli P, Kiss P, Porru S, Bonde JP, Vanhoorne M. Male reproductive toxicity of lead in animals and humans. ASCLEPIOS Study Group. Occup Environ Med 1998;55(6):36474.

24. Saaranen M, Suistomaa U, Kantola M, Saarikoski S, Vanha-Perttula T. Lead, magnesium, selenium and zinc in human seminal fluid comparison with semen parameters and fertility. Hum Reprod 1987;2(6):475-9,

25. Lerda D. Study of sperm characteristics in persons occupationally exposed to lead. Am J Ind Med 1992;22(4):567-71.

26. Telisman $\mathrm{S}$, Cvitković $\mathrm{P}$, Jurasović J, Pizent A, Gavella M, Rocić B. Semen quality and reproductive endocrine function in relation to biomarkers of lead, cadmium, zinc, and copper in men. Environ Health Perspect 2000;108(1): 45-53.

27. Cullen MR, Kayne RD, Robins JM. Endocrine and reproductive dysfunction in men associated with occupational inorganic lead intoxication. Arch Environ Health 1984;39(6):431-40.

28. Liou SH, Yang GY, Wu TN, Ko YC, Lee CC, Ho ST, et al. Assessment of interlaboratory performance on the measurement of blood lead levels in Taiwanese adults. Ind Health 1995;33(4):181-90.

29. Joffe M, Bisanti L, Apostoli P, Kiss P, Dale A, Roeleveld N, et al. Time to pregnancy and occupational lead exposure. Occup Environ Med 2003;60(10):752-8.

30. Rabinowitz M, Wetherill GW, Kopple JD. Studies of human lead metabolism by use of stable isotope tracers. Environ Health Perspect 1974;7:145-53. 
31. Lancranjan I, Popescu HI, GAvănescu O Klepsch I, Serbănescu M. Reproductive ability of workmen occupationally exposed to lead. Arch Environ Health 1975;30(8):396-401.

32. Gennart JP, Buchet JP, Roels H, Ghyselen P, Ceulemans $E$, Lauwerys R. Fertility of male workers exposed to cadmium, lead, or manganese. Am J Epidemiol 1992;135(11):1208-19.

33. Coste J, Mandereau L, Pessione F, Bregu M, Faye C, Hemon D, et al. Lead-exposed workmen and fertility: a cohort study on 354 subjects. Eur J Epidemiol 1991;7(2):154-8.

34. Xu B, Chia SE, Ong CN. Concentrations of cadmium, lead, selenium, and zinc in human blood and seminal plasma. Biol Trace Elem Res 1994;40(1):49-57.

35. Tielemans $E$, Burdorf $A$, te Velde ER, Weber RF, van Kooij RJ, Veulemans H, et al. Occupationally related exposures and reduced semen quality: a case-control study. Fertil Steri 1999;71(4):690-6.

36. Curtis KM, Savitz DA, Arbuckle TE. Effects of cigarette smoking, caffeine consumption, and alcohol intake on fecundability. Am J Epidemiol 1997;146(1):32-41.

37. Gaur DS, Talekar M, Pathak VP. Effect of cigarette smoking on semen quality of infertile men. Singapore Med J 2007;48(2):119-23.
38. Vine MF. Smoking and male reproduction: a review. Int J Androl 1996;19(6):323-37.

39. Osser S, Beckman-Ramirez A, Liedholm P. Semen quality of smoking and non-smoking men in infertile couples in a Swedish population. Acta Obstet Gynecol Scand 1992;71(3): 215-8.

40. Chia SE, Ong CN, Tsakok FM. Effects of cigarette smoking on human semen quality. Arch Androl 1994;33(3):163-8.

41. Oldereid NB, Thomassen Y, Purvis K. Seminal plasma lead, cadmium and zinc in relation to tobacco consumption. Int J Androl 1994;17(1): 24-8. 
Copyright of Turkiye Klinikleri Journal of Medical Sciences is the property of Ortadogh Reklam Tanitim ve Yayincilik Turizm Egitim Insaat Sanayi ve Ticaret A.S. and its content may not be copied or emailed to multiple sites or posted to a listserv without the copyright holder's express written permission. However, users may print, download, or email articles for individual use. 